\title{
The Expression of Dehydrin Genes and the Intensity of Transpiration in Drought-stressed Maize Plants
}

\author{
J. KlimeŠOvÁ*, L. HolkovÁ and T. StŘedA \\ Department of Crop Science, Breeding and Plant Medicine, Faculty of AgriSciences, \\ Mendel University in Brno, Zemědělská 1, 61300 Brno, Czech Republic
}

(Received 4 April 2016; Accepted 27 December 2016;

Communicated by A. Mohan)

\begin{abstract}
The stress reaction of maize plants was evaluated in relation to drought stress intensity and to growth stages by assessing the transpiration intensity and the expression of two dehydrin genes, DHN1 and DHN2. The maize plants were grown under four different watering conditions: well-watered (control), mild stress, moderate stress and high stress. The sap flow values were taken as an indicator of plant stress reactions at the transpiration level. A significant correlation between the average diurnal values of sap flow and the volumetric soil moisture appeared only for the moderate stress condition $(\mathrm{R}=0.528)$ and for the high stress condition $(\mathrm{R}=0.395)$. Significant increases in the expression of DHN1 and DHN2 (DHN1 = $10^{5}$-fold and $D H N 2=10^{3}$-fold) were observed primarily for the high stress condition compared to the control. Differences in the stress reactions at the DHN1 gene expression level were detected for all the experimental drought stress conditions. A relatively close relationship between the levels of expression of both genes and the values of the sap flow was observed during the initial stage of the stress $(\mathrm{R}=-0.895 ; \mathrm{R}=-0.893)$. The severity of water stress and transpiration intensity significantly affected certain biometric and yield parameters of maize. Higher $D H N$ genes expression at the ripening stage was related to lower grain and dry biomass yield. The results indicated that $D H N$ gene expression assessment in maize and evaluation of the changes in transpiration expressed by the sap flow could be considered appropriate indicators of stress intensity while the $D H N$ gene expression assessment appeared to be more sensitive than evaluation of the changes in transpiration, mainly in the initial phases of stress response.
\end{abstract}

Keywords: drought stress, sap flow, meteorological factors, DHN1, DHN2

\section{Introduction}

Drought is the most significant environmental stress worldwide, therefore improving yields under drought conditions is a major goal of plant breeding. The significance of drought effects increases with the time of exposure during the vegetative period and during the critical phases of plant development (Grzesiak et al. 2013). For maize, the critical periods are the time of flowering and the early maturity phase (Doorenbos and Kassam 1979; Zinselmeier et al. 2002). Changes in transpiration can indicate the effects of stress 
on plants. The flow of water (sap) in the xylem, which is supported by different water potentials in the leaves and ambient air, can be measured using sensitive methods based on heat transfer (Kučera et al. 1977).

Plant protective mechanisms at the cellular level include the induction of the synthesis of a range of proteins. The functions of dehydrins (DHNs, LEA D11 family) have been studied in relation to cellular protective mechanisms. DHNs are a subfamily of group 2 late embryogenesis abundant (LEA) proteins that accumulate at high levels during the late stages of seed development and in vegetative tissues subjected to water deficits, salinity, low temperature, or abscisic acid (ABA) treatment (Close 1997). Thus, DHNs are often linked to drought tolerance (Guo et al. 2009) and acclimatisation processes that lead to higher resistance to frost (Ganeshan et al. 2009).

The sequences of two DHN genes, DHN1 and DHN2, are currently known in maize. The conditions of activation, structure and function, as well as promoter regulation, have been studied in plant cells (Vilardell et al. 1991; Koag et al. 2003; Capelle et al. 2010). The assessment of $D H N$ gene expression or the quantitative evaluation of DHN protein concentrations in multiple genotypes under given stress conditions may be utilised for testing and comparing the sensitivity of these genotypes to drought stress (e.g. Badicean et al. 2011). The evaluation of $D H N$ gene expression or protein accumulation may also be used as an indicator of stress intensity and of plant responses to stress conditions (Tommasini et al. 2008; Vítámvás et al. 2015).

Two different strategies have been described for the drought stress reaction of maize. Benešová et al. (2012) reported that the more tolerant genotype showed a slower closing of stomata, which resulted in a greater loss of water from the tissues; however, this genotype yielded a greater efficiency of photosynthesis for a longer time and a related higher level of synthesis of protective proteins, including DHN1, under mild stress than in the more sensitive genotype. According to results published by Gholipoor et al. (2013), drought-tolerant genotypes exhibited decreased transpiration rates at an earlier stage in the soil drying cycle than other less water-conserving genotypes, thereby conserving more water for later use if the drought persisted.

Although it is known that drought stress during anthesis and early maturity stage affect the maize plants substantially, no studies related to $D H N$ genes expression and transpiration rate have been conducted with mature maize plants. Sorghum plants [Sorghum bicolor (L.) Moench.] in 12 leaves stage showed an enhanced DHN1 gene expression several days after restriction of watering in the pot experiment (Wood and Goldsbrough 1997). Authors state that the gene expression is an indicator of drought stress and relevant adaptation mechanism. DHN1 gene expression in sunflower plants was strongly dependent on the soil moisture and the parameters of the plant water status and therefore this process was considered a highly sensitive marker of water stress (Aguado et al. 2014). $D H N$ gene locus has been associated with the anthesis-silking interval (ASI) in the drought stressed maize plants (Campbell and Close 1997). ASI is a phenotypic manifestation of drought stress and yield reduction in maize plants. Statistically significant relationship between the ASI and maize grain yield has been found (Ribaut et al. 1996; Li et al. 2003). 
The objective of the present study was to determine the intensity of the stress response of maize plants (Zea mays L.) using physical (sap flow) and molecular methods to quantify the stress reaction with respect to the plant growth phase and the drought intensity and to evaluate the relations between these stress parameters and the effects on the yield of stressed plants.

\section{Materials and Methods}

\section{Plant material and growing conditions}

The experiments were performed on drought-tolerant maize (Zea mays L.) line 2087 plants. The experimental plant material was selected in detailed field trials in maize breeding station CEZEA in Čejč, Czech Republic. Drought tolerance of this line was confirmed also in our independent pot experiment (unpublished data). Pot experiments were established under natural conditions with limited irrigation. The plants were maintained under four different watering conditions beginning at phase $\mathrm{BBCH} 40$ (Meier 1997). Based on the soil analysis, the field water capacity was 39 volume $\%$ of water, and the wilting point was 21 volume $\%$ of water. Condition A, the control, was $90 \%$ available water holding capacity (AWHC) (Klimešová et al. 2013), condition B was mild stress at $50 \%$ AWHC, condition $\mathrm{C}$ was moderate stress at 25\% AWHC, and condition D was high stress at $23 \%$ volumetric soil moisture and $15 \%$ AWHC.

Containers of $200 \mathrm{dm}^{3}$ volume and dimensions of $73 \times 54 \times 51 \mathrm{~cm}$ were planted with 6 maize plants each. The plants were continuously monitored for their phenological phases and later for stress-induced changes in their growth. The dry matter yield of whole plants, grain yield, plant height, stem diameter and harvest index was evaluated for all plants in each variant of the experiment $(n=6)$ in the stage of full maturity $(\mathrm{BBCH} 89)$.

\section{Sap flow measurement}

Transpiration was monitored using continuous xylem sap flow measurement. An EMS 62 sap flow system (EMS Brno, CZ), which uses the "stem heat balance" method (Kučera et al. 1977), was used to measure xylem sap flow. Stem heat balance is a non-destructive method for the continuous measurement of sap flow in herbaceous species using direct electrical heating of tissue and internal temperature sensing. The sap flow values are provided in 10-min intervals in $\mathrm{kg} \cdot \mathrm{h}^{-1}$. The diurnal sap flow values were used for analysis only. Two plants from each condition were sampled at different times between phase BBCH 50 (heading) and phase BBCH 89 (full maturity).

\section{Meteorological variables}

Meteorological conditions were monitored simultaneously. The relative air humidity [\%] and air temperature $\left[{ }^{\circ} \mathrm{C}\right]$ were measured at 10-min intervals using HOBO U23 Pro V2 sensors (Onset Computer Corporation, Bourne, MA, USA). The soil moisture content 
[\%] was measured at 15-min intervals using VIRRIB automatic electromagnetic sensors (AMET Velké Bílovice, $\mathrm{CZ}$ ) with an accuracy of $\pm 1 \%$, and the soil temperature $\left[{ }^{\circ} \mathrm{C}\right]$ was measured at 15-min intervals using Pt100 resistance sensors. The global solar radiation, i.e. the total amount of solar energy received by the Earth's surface $\left[\mathrm{W} \cdot \mathrm{m}^{-2}\right]$ was measured using LI-COR sensors (LI-COR Biosciences, Lincoln, NE, USA) at 15-min intervals. Photosynthetically active radiation (PAR, spectral range 400-700 nanometers) is the most essential part of solar radiaton for plants. However, solar radiation is measured as the global solar radiation in meteorology (Jacovides et al. 2003). The water potential of the soil [-bar] was ascertained by a gypsum block connected to a MicroLog SP datalogger (EMS Brno, CZ) at 10-min intervals.

\section{Data processing and statistical analysis}

The experimental data were processed using MINI32 software (EMS Brno, CZ) and statistically evaluated using STATISTICA 10 software (StatSoft Inc., Tulsa, OK, USA). The analyses performed included correlation analysis, variance analysis and consequent testing by the Tukey HSD test.

\section{Analyses of dehydrin genes expression}

A leaf tissue was sampled on three dates, August 7 (2 weeks of drought stress, BBCH 63), August 14 (3 weeks of drought stress, BBCH 67), August 28 (5 weeks of drought stress, $\mathrm{BBCH} 75$ ) and September 4 (6 weeks of drought stress, BBCH 83-85), to assess the expression of the selected genes.

Total RNA was isolated from $100 \mathrm{mg}$ leaf discs taken from the second youngest leaf using the RNeasy Plant Mini Kit (Qiagen, Hilden, Germany). RNA purification was performed using the Turbo DNase Kit (Ambion, Austin, TX, USA). The first cDNA chain was synthesised from $1 \mu \mathrm{g}$ of purified total RNA using the QuantiTect ${ }^{\circledR}$ Reverse Transcription Kit (Qiagen, Hilden, Germany), and qPCR reactions were performed using the QuantiTect ${ }^{\circledR}$ SYBR ${ }^{\circledR}$ Green PCR Kit (Qiagen, Hilden, Germany) with gene-specific primers for DHN1 (5'-GAAGGAGGAAGAAGGGAAT-3'/5'-ACTGTCCCTGTCCCTGTCAC-3') and DHN2 (5'-ACGTTTTTCGCCGATCATGG-3'/5'-CCCTGTCCTTCACCTCG-TTC-3'). These primers were designed according to the maize DHN1 and DHN2 sequences (GenBank Accession No. NM001111949 and L35913). The ubiquitin gene was amplified with specific primers as a reference gene (Gómez-Anduro et al. 2011). The expression stability of this gene under our experimental conditions and at different developmental stages was checked using BestKeeper software (Pfaffl et al. 2004).

The qPCR reaction mixtures $(25 \mu \mathrm{l})$ consisted of $1 \times$ QuantiTect SYBR Green PCR master mix $\left(2.5 \mathrm{mM} \mathrm{MgCl}_{2}\right), 0.2 \mu \mathrm{M}$ forward primer, $0.2 \mu \mathrm{M}$ reverse primer, and the cDNA equivalent to $50 \mathrm{ng}$ of the original RNA ( $2 \mathrm{ng} / \mu 1$ of the reaction mix).

The conditions for qPCR were as follows: $95^{\circ} \mathrm{C}$ for 15 minutes and then 40 cycles of $94{ }^{\circ} \mathrm{C}$ for $15 \mathrm{~s}, 57-60^{\circ} \mathrm{C}$ for $20 \mathrm{~s}$, and $72{ }^{\circ} \mathrm{C}$ for $30 \mathrm{~s}$. An annealing temperature $\left(\mathrm{T}_{\mathrm{an}}\right)$ of $57^{\circ} \mathrm{C}$ was used for $\mathrm{DHN} 2$ and for the ubiquitin gene, and $60^{\circ} \mathrm{C}$ was used for the $\mathrm{DHN} 1$ 
gene. The specificity of the reaction was confirmed by a "melting" analysis of the PCR products. Gene expression was evaluated as the relative gene expression calculated according to Pfaffl (2001).

The results are presented as normalised relative gene expression levels (NRE) relative to the value of the internal calibrator, i.e. the DHN1 gene expression level of the first sample of the control variant. The values in the graph are presented as the averages of three independent samples that were measured twice \pm SD.

\section{Results}

The sap flow in relation to weather and soil variables

The vegetative period of maize was divided into three periods according to the changes in transpiration and to the phenological phase of the plants (Period I: 27 July-7 August, BBCH 53-63; Period II: 8-24 August, BBCH 63-73; Period III: 25 August-14 September, BBCH 73-89). The dependence of transpiration on environmental factors (global solar radiation and air temperature) was assessed separately for each of the periods (see Table $\mathrm{S} 1 *$ ).

A statistically significant dependence of transpiration on selected meteorological variables, including global solar radiation $(\mathrm{R}=0.439-0.881$ for individual variants in period I and $R=0.563$ and 0.670 in period II $)$ and air temperature $(R=0.698-0.934$ for individual variants in period I and $\mathrm{R}=0.030-0.627$ in period II), was observed. The relations between transpiration intensity and meteorological variables differed for different growth phases and conditions. The level of sap flow $(z)$ in period I of the control condition relative to global solar radiation $(y)$ and air temperature $(x)$ can be characterised by the equation $\left(\mathrm{R}^{2}=0.977\right)$ :

$$
z=(a+b x+c y) /(1+d x+f y)
$$

(equation coefficient values: $a=-1.07 \times 10^{-3} ; b=8.24 \times 10^{-6} ; c=1.92 \times 10^{-5} ; d=-2.79 \times$ $\left.10^{-2} ; f=5.14 \times 10^{-5}\right)$.

The level of sap flow in period I of stress condition $\mathrm{D}$ is characterised by the equation $\left(\mathrm{R}^{2}=0.807\right)$ :

$$
z=(a+b[\ln (x)]+c[\ln (y)] /(1+d x+f y)
$$

(equation coefficient values: $a=-3.67 \times 10^{8} ; b=9.54 \times 10^{7} ; c=1.01 \times 10^{7} ; d=1.54 \times 10^{7}$; $\left.f=1.02 \times 10^{6}\right)$.

The intensity of the drought conditions influenced plant transpiration only in the two most stressed cases, i.e. C and D. The relation between average diurnal sap flow values $\left(\mathrm{kg} \cdot \mathrm{h}^{-1}\right)$ and the volumetric soil moisture was evaluated for the entire vegetative period. Statistically significant relations were evident for conditions $\mathrm{D}\left(\mathrm{R}=0.528^{* *}, \mathrm{n}=48\right)$ and $\mathrm{C}\left(\mathrm{R}=0.395^{* *}, \mathrm{n}=48\right)$. Effect of soil water availability on the transpiration rate increases when soil moisture drops to the stress level and simultaneously the dependence of

*Further details about the Electronic Supplementary Material (ESM) can be found at the end of the article. 


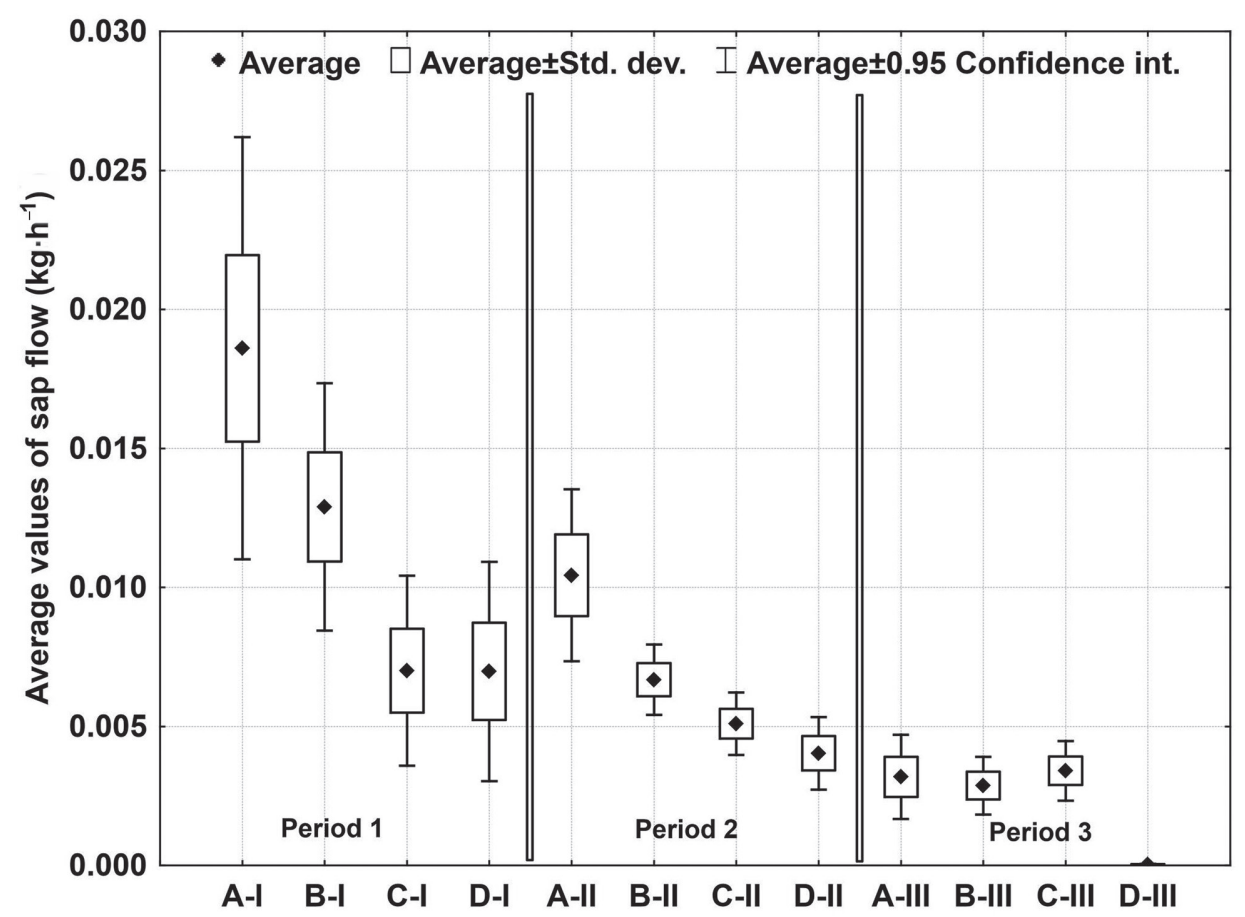

Figure 1. Average diurnal sap flow values $\left(\mathrm{kg} \cdot \mathrm{h}^{-1}\right)$ of maize plants $(\mathrm{n}=2)$ for all the irrigation conditions (A: control, 90\% AWHC B: 50\% AWHC, C: 25\% AWHC, and D: 15\% AWHC) in the three measured periods of maize vegetation (I, II and III)

sap flow values on global solar radiation and air temperature decreases. Optimally irrigated plants $(\mathrm{A}$ - control) at the flowering phase transpirated on average $18.61 \mathrm{~g}$ of water per hour. The transpiration was $30 \%$ lower in condition $\mathrm{B}\left(12.90 \mathrm{~g} \cdot \mathrm{h}^{-1}\right)$ and $60 \%$ lower in conditions $\mathrm{C}$ and $\mathrm{D}\left(7.0 \mathrm{~g} \cdot \mathrm{h}^{-1}\right.$ and $\left.6.98 \mathrm{~g} \cdot \mathrm{h}^{-1}\right)$ at the beginning of the measured period (flowering) than in the control (Fig. 1). The maize sap flow of experimental conditions was less different with an extended period of limited watering and the age of plants. The transpiration flow was almost identical $\left(3 \mathrm{~g} \cdot \mathrm{h}^{-1}\right)$ for all the experimental conditions (with differences being non-significant, see Fig. 1) at the end of the growing period in early September (BBCH 83-85).

\section{Evaluation of the DHN gene expression}

The expression levels of both of the monitored $D H N$ genes were measured in three dates during the vegetative period (Fig. 2). Based on the use of a common internal calibration of the normalized relative expression (NRE) of both genes (the DHN1 gene expression level of the first sample of the control variant), the expression of DHN2 was clearly higher than the expression of $D H N 1$, and this difference in expression was particularly 


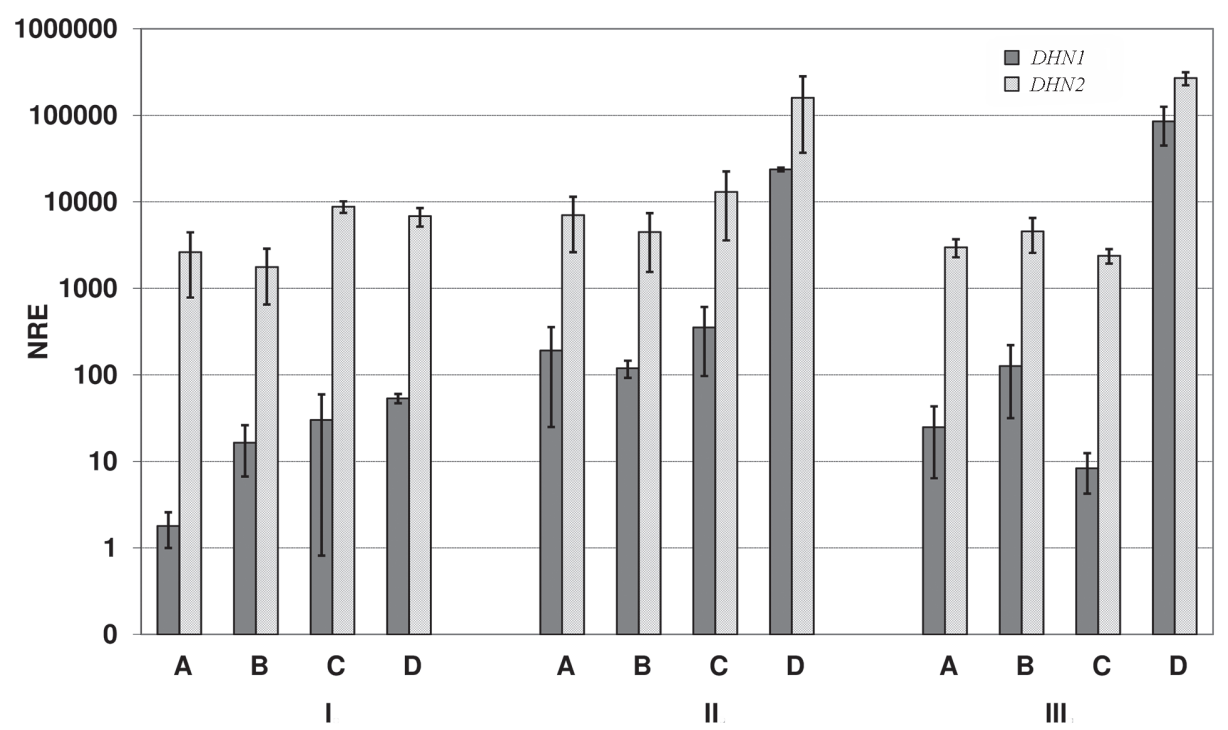

Figure 2. Evaluation of the normalised relative expression (NRE) of the DHN1 and DHN2 genes in the leaves of maize plants cultivated under different drought stress conditions (A: 90\% AWHC; B: 50\% AWHC; C: 25\% AWHC; and D: 15\% AWHC) and sampled on three dates (I: 2 weeks of drought stress, BBCH 63; II: 3 weeks of drought stress, BBCH 67; and III: 5 weeks of drought stress, BBCH 75). The logarithms of the NRE values are presented as averages of 3 independent samples measured twice $\pm \mathrm{SD}$

obvious for the irrigated control. In the first sampling (after 2 weeks of drought stress, $\mathrm{BBCH} 63$ ), the control plants showed $10^{3}$-fold higher expression of the DHN2 gene. During the experiment, the NRE values of DHN2 fluctuated by only single-digit values, whereas the expression of the $D H N 1$ gene changed significantly during maturation. The youngest control plants displayed minimal expression levels of this gene at the first sampling; the maximum expression level of $D H N 1$ was reached at the second sampling (300fold compared to control plants in the first sampling).

The influence of different intensities and durations of stress on the expression levels of both genes was monitored in individual plants under all experimental conditions. At the first sampling ( 2 weeks of drought stress), the expression of the DHN1 gene increased by an average of 8 -fold in condition B (50\% available water holding capacity - AWHC), 15 -fold in condition $\mathrm{C}(25 \% \mathrm{AWHC})$ and 27 -fold in condition D (15\% AWHC) relative to the control. Moreover, increased expression levels of the DHN2 gene were noted under conditions C and D. However, compared to the irrigated control (condition A), the increases in the expression levels of this gene were only 3.3-fold under condition $\mathrm{C}$ and 2.6-fold under condition D.

The length of drought stress influenced the levels of expression of both genes. In the second sampling ( 3 weeks of drought stress), the expression of DHN1 increased 100-fold compared with the first sampling under all the conditions, including the control. Only the plants under the most stressful condition, D, showed a highly significant increase in the 
expression of this gene; the expression level was about 100-fold higher than that of the control assessed on the same date. Similar increases were reflected in the NRE of the DHN2 gene. The levels of expression of DHN2 in the non-stressed control, condition A, and condition B were similar. A small increase in the NRE of DHN2 was noted under condition $\mathrm{C}$ (a 2-fold increase compared to the irrigated control sampled at the same time). Similar to $D H N 1$, a significant increase in the expression of $D H N 2$ was noted under the most stressful condition D. The NRE of DHN2 was 23-fold higher than the NRE of the control sampled at the same time.

In the third sampling, we observed decreased expression levels of both genes in the irrigated control and, simultaneously, a further increase in the expression of both genes under the most stressful condition, D. The NRE expression of the DHN1 gene increased $3 \times 10^{3}$-fold compared with the irrigated control in the same sampling. The levels of expression of DHN1 and DHN2 under condition B remained the same as in the previous sampling; however, under condition $\mathrm{C}$, the NRE values of both genes dropped to the levels of the values in the first sampling of the irrigated control.

\section{DHN gene expression in relation to transpiration and yield parameters}

The relation between the levels of expression of both genes and the physiological condition of the plants (expressed by sap flow values) was assessed for individual samples. Relatively high negative correlation coefficients (see Table 1) indicated an indirect relation between the two processes. The highest absolute values of the correlation coefficients $(\mathrm{n}=4)$ were obtained during the first samplings $(\mathrm{R}=-0.895 /-0.833)$. The strength of correlation between the sap flow values and the expression of DHN1 and DHN2 gene, respectively, was almost identical in all periods. However, gene expression in plants exposed to drought stress for 5 weeks (Period III) was not accompanied by a proportional sap flow decrease. Differences in maize sap flow were statistically non-significant for the watering regimes $\mathrm{A}, \mathrm{B}$ and $\mathrm{C}$ in this period (Fig. 1).

The relations among the levels $D H N$ gene expression, plant height and stem diameter and two yield parameters were evaluated. The values of Pearson's correlation coefficient (R) are summarised in Table 2. Correlations between DHN1 gene expression and the yield parameters were lower most likely due to a lower effect of stress on yield during this first period. More significant relations among the expression of both genes and two yield

Table 1. Comparisons of the sap flow (SF) values with the normalised relative expression (NRE) values of the DHN1 and DHN2 genes as a function of the duration of the drought stress and as a function of the growth phase of the plants in all four water regime conditions $(n=4)$

\begin{tabular}{|l|c|c|c|c|c|}
\hline \multicolumn{1}{|c|}{ Sampling date } & BBCH phase & $\begin{array}{c}\text { Duration of stress } \\
\text { (weeks) }\end{array}$ & Period* & SF/NRE DHN1 & SF/NRE DHN2 \\
\hline 7 Aug. 2012 & 63 & 2 & I & -0.895 & -0.833 \\
\hline 14 Aug. 2012 & 67 & 3 & II & -0.628 & -0.650 \\
\hline 28 Aug. 2012 & 75 & 5 & III & -0.647 & -0.647 \\
\hline
\end{tabular}

*Period according to transpiration intensity changes. 
Table 2. Correlation (R) between the levels of normalised relative expression (NRE) of the $D H N$ genes for three vegetation periods and the selected morphological and yield parameters of the plants in all four water regime conditions $(n=4)$

\begin{tabular}{|c|c|c|c|c|c|}
\hline Periods & NRE & Plant height & Stem diameter & Dry matter yield & Grain yield \\
\hline \multirow{3}{*}{ I } & DHN1 & $-0.985^{*}$ & -0.927 & -0.772 & -0.805 \\
\cline { 2 - 6 } & DHN2 & -0.681 & -0.754 & -0.188 & -0.319 \\
\hline \multirow{2}{*}{ II } & DHN1 & -0.771 & -0.927 & $-0.982^{*}$ & $-0.996^{* *}$ \\
\cline { 2 - 6 } & DHN2 & -0.784 & -0.754 & $-0.974^{*}$ & $-0.994^{* *}$ \\
\hline \multirow{2}{*}{ III } & DHN1 & -0.769 & -0.599 & $-0.983^{*}$ & $-0.996^{* *}$ \\
\cline { 2 - 6 } & DHN2 & -0.768 & -0.598 & $-0.984^{*}$ & $-0.996^{* *}$ \\
\hline
\end{tabular}

Significant values $(\mathrm{P} \leq 0.05)$ are marked with an asterisk $\left({ }^{*}\right)$, and highly significant values $(\mathrm{P} \leq 0.01)$ are marked with a double asterisk $(* *)$.

parameters were observed with the increasing durations of stress (periods II and III) (from $\mathrm{R}=-0.974 * *$ to $\mathrm{R}=-0.996 * *)$.

Although biometric parameters, plant height in particular, were affected by sap flow rate (Table 3) and watering regime (Table 4), gene expression was not related to the growth characteristics in plants (with the exception of NRE of DHN1 gene and plant height in period I).

Table 3. Correlations between the sap flow for three vegetation periods and the selected morphological and yield parameters of the plants in all four water regime conditions $(n=4)$. Period III was divided into two sections due to the different responses of biometric and yield parameters of maize to the sap flow changes at the grain filling stage

\begin{tabular}{|c|c|c|c|c|c|}
\hline Periods & Plant height & Stem diameter & Dry matter yield & Grain yield & Harvest index \\
\hline I & 0.937 & $0.989^{*}$ & 0.408 & 0.455 & 0.452 \\
\hline II & $0.958^{*}$ & $0.983^{*}$ & 0.504 & 0.560 & 0.558 \\
\hline IIIa & $0.970^{*}$ & $0.970^{*}$ & 0.590 & 0.577 & 0.572 \\
\hline IIIb & 0.772 & 0.600 & $0.989 *$ & $0.966^{*}$ & $0.964^{*}$ \\
\hline
\end{tabular}

Significant values $(\mathrm{P} \leq 0.05)$ are marked with an asterisk $(*)$.

Table 4. The impact of drought stress on the selected biometric and yield characteristics of maize plants grown under different soil moisture conditions $(n=24)$

\begin{tabular}{|c|c|c|c|c|c|}
\hline Watering regimes & $\begin{array}{c}\text { Plant height } \\
(\mathrm{cm})\end{array}$ & $\begin{array}{c}\text { Stem diameter } \\
(\mathrm{mm})\end{array}$ & $\begin{array}{c}\text { Dry matter yield } \\
(\mathrm{g})\end{array}$ & $\begin{array}{c}\text { Grain yield } \\
(\mathrm{g})\end{array}$ & Harvest index \\
\hline A & $179.67^{\mathrm{a}}$ & $20.50^{\mathrm{a}}$ & $128.20^{\mathrm{a}}$ & $40.93^{\mathrm{a}}$ & $0.31^{\mathrm{a}}$ \\
\hline $\mathrm{B}$ & $167.83^{\mathrm{ab}}$ & $19.17^{\mathrm{a}}$ & $126.61^{\mathrm{a}}$ & $44.31^{\mathrm{a}}$ & $0.34^{\mathrm{a}}$ \\
\hline C & $162.00^{\mathrm{bc}}$ & $18.33^{\mathrm{a}}$ & $132.27^{\mathrm{a}}$ & $44.81^{\mathrm{a}}$ & $0.34^{\mathrm{a}}$ \\
\hline $\mathrm{D}$ & $152.17^{\mathrm{c}}$ & $18.00^{\mathrm{a}}$ & $103.30^{\mathrm{a}}$ & $4.14^{\mathrm{b}}$ & $0.04^{\mathrm{b}}$ \\
\hline
\end{tabular}

*Statistically different pairs $(\mathrm{P} \leq 0.05)$ are indicated by different letters. 
Period III was divided into two sections due to the different responses of biometric and yield parameters of maize to the sap flow changes at the grain filling stage. The intensity of transpiration significantly affected morphological parameters - plant height and stem diameter, particularly in flowering and early grain filling stage during periods I, II and IIIa (BBCH 53-73) (from $\mathrm{R}=0.958 *$ to $0.989 *$ ). Significant relations between the intensity of transpiration and the measured yield parameters were detected only during period IIIb in grain filling stage (BBCH 73-89) (from $\mathrm{R}=0.964 *$ to $0.989^{*}$ ). The amount of water available during the flowering and grain filling periods affected transpiration and, consequently, plant growth. The lack of soil moisture during the period of physiological grain maturity and the long stress duration reduced both the dry matter yield and grain yield.

Statistically significant differences among the biometric parameters assessed using analysis of variance are presented in Table 4 . The highest values of stem diameter and plant height were recorded in the irrigated control plants. The plants grown under stressed conditions $\mathrm{C}$ and $\mathrm{D}$ showed significantly lower height and stem diameter values (no significant differences) than plants in the irrigated control. Significantly lower transpiration flow values were also detected in conditions $\mathrm{C}$ and $\mathrm{D}$ than in the irrigated control, but only plants in condition D provided significantly lower dry matter yields of biomass (78.1\%) and grain $(9.2 \%)$ compared to most yielding plants in condition $\mathrm{C}$.

\section{Discussion}

In a study by Gholipoor et al. (2013), sap flow measurements proved an accurate indicator of the water flow and transpiration rates relative to abiotic stress parameters (drought and intensity of light) for maize. With increased evapotranspiration requirements (depending on the daily variation in global solar radiation and air temperature), the transpiration rate was higher compared with the rates under water-stressed conditions. Novák et al. (2005) also confirmed these results. The limited amount of water in the soil that is available for plants caused a significant drop in the transpiration intensity under conditions $\mathrm{C}$ and $\mathrm{D}$ ( $25 \%$ and $15 \%$ AWHC, i.e. moderate and severe water stress, respectively). Wu et al. (2011a) described a similar effect of the soil moisture level on transpiration in maize. The transpiration of plants decreased during both daily and seasonal periods with decreasing soil water content in relation to the evapotranspiration conditions of the environment. The sensitivity threshold of maize transpiration to the availability of soil moisture may also be influenced by the genotype (Gholipoor et al. 2013; Leitner et al. 2014). Compared with the soil moisture content at full field capacity, an AWHC decrease of $20 \%$ resulted in a statistically significant decrease in the amount of transpired water by maize plants (Wu et al. 2011b). These results were only confirmed in our experiment towards the end of the maize grain maturation period (during the formation of seeds and maturation, $\mathrm{BBCH}$ 73-83) for all the stress conditions tested (B, C, and D).

Many authors have considered drought stress by achieving the soil moisture at 50$60 \%$ of AWHC. Jamieson et al. (1995) found changes in barley transpiration at a soil water content less than 65\% of AWHC. Similarly, Matejka et al. (2005) noted changes in modelled maize evapotranspiration, if the soil moisture dropped below $58.2 \%$ of AWHC. 
The soil water content at $15 \%$ to $25 \%$ of AWHC can thus be considered a significant drought stress for most of the agricultural crops.

However, significant decline in sap flow values (sap flow in condition B decreased by $30 \%$ and in condition D by nearly $70 \%$ compared to the control) in stress conditions was not connected to grain and dry biomass yield reduction. The differences between the irrigated control and the plants in conditions $\mathrm{B}(50 \% \mathrm{AWHC})$ and $\mathrm{C}(25 \% \mathrm{AWHC})$ were not statistically significant. In contrast to the results of Grzesiak et al. (2012), maize plants grown under field conditions of drought stress (soil water content $30 \%$ of field water capacity) provided a grain yield of up to $55.8 \%$ of the grain yield of control plants. These results suggest that maize line 2087 is drought-tolerant.

The transpiration intensity also influenced the selected biometric characteristics in relation to phenological stage of plant growth. Plant height was affected especially during the flowering and early generative phases. A significant effect of transpiration on maize plants height in dependence on soil moisture was also confirmed by Gavloski et al. (1992). Interesting reduction of plant height of up to $30 \mathrm{~cm}$ in the condition D compared with control did not result in a statistically significant yield loss of dry biomass. This phenomenon is probably caused by thickening of cell wall and reducing their growth. Cell wall hardening was observed in the leaves of maize exposed to drought stress induced by PEG solution (Chazen and Neumann 1994). Valluru et al. (2016) observed even increase of shoot dry biomass but only in drought tolerant wheat genotypes grown in conditions of mild drought stress. They concluded that shoot dry biomass might be distinctly regulated by specific ABA:ethylene ratio depending upon the drought sensitivity of the tested genotypes.

The evaluation of DHN1 and DHN2 expression was performed on maturing embryos (Capelle et al. 2010) or on young plants that were exposed, in most cases, to high stress, including 20\% PEG, irrigation blockage (Zheng et al. 2004) or drying after the plants were pulled out of the soil (Badicean et al. 2011). Our evaluation focused on (i) the course of regulation of these two $D H N$ genes in plants exposed to long-term drought conditions of different intensities, (ii) whether the levels of expression of these genes correlated with the intensity of stress and with the physiological stress reactions of the plants as assessed by sap flow. The level of DHN2 expression was 1000-fold higher at the start of the assessment than the level of DHN1 expression. Capelle et al. (2010) observed similar differences in the expression of both genes (DHN1 and DHN2) while assessing gene expression during grain maturation.

The increased level of DHN1 gene expression detected in the second sampling of the irrigated control was most likely the result of the significant reductions in sap flow and transpiration (data not shown) during the period approximately 5 days before the second sampling. This decrease in transpiration was likely due to the drop in day temperatures by ca. $5{ }^{\circ} \mathrm{C}$ (average daily temperatures varied by approximately $15^{\circ} \mathrm{C}$ ) with parallel radiation level fluctuations $\left(800 \mathrm{~W} \cdot \mathrm{m}^{-2} \times 450 \mathrm{~W} \cdot \mathrm{m}^{-2} \times 800 \mathrm{~W} \cdot \mathrm{m}^{-2}\right)$. Thus, the increased expression of the DHN1 gene in the control was most likely caused by a short-term stress. Non-acclimatised plants in the irrigated control were most likely more sensitive to a short-term stress than the plants in the long-term stress conditions. The DHN genes are 
known to be activated by transcription factors that can be regulated by ABA and by ethylene, and these genes could be involved cooperatively or separately in the response to various environmental stresses (Jia et al. 2006).

The levels of expression of both genes were extremely high in our experiments. An increase in the relative expression by several orders of magnitude compared to the control $\left(\right.$ DHN1 $=10^{5}$-fold and $D H N 2=10^{3}$-fold $)$ has not previously been recorded. A maximum of 30-60-fold increase in DHN1 protein synthesis in the leaves of young plants was reported by Benešová et al. (2012) after 6 days of mild stress (12.5\% soil moisture content). Our results suggested that severe drought stress conditions can lead to the intensive synthesis of DHNs in the leaf tissues of maize even during the flowering and grain maturation phases. A similar level of expression of both genes was observed repeatedly in our independent experiment (not yet published).

The comparison of the stress reactions of plants at physiological and molecular levels using correlation coefficients showed that the relative expression levels of the $D H N$ genes could be more sensitive indicators of stress responses than the physiological parameters under certain conditions, particularly during the initial phases of stress. DHN genes expression was confirmed as a sensitive method for evaluation of stress intensity due to good agreement with physiological (sap flow), biometric traits (dry matter yield, grain yield, plant height) and soil moisture conditions.

\section{Acknowledgements}

This work was funded by project No. TP 10/2012 of the Internal Grant Agency IGA of the Mendel University in Brno and by project No. QJ1510098 of the National Agency for Agricultural Research.

\section{References}

Aguado, A., Capote, N., Romero, F., Dodd, I.C., Colmenero-Flores, J.M. 2014. Physiological and gene expression responses of sunflower (Helianthus annuus L.) plants differ according to irrigation placement. Plant Sci. 227:37-44.

Badicean, D., Scholten, S., Jacota, A. 2011. Transcriptional profiling of Zea mays genotypes with different drought tolerances - new perspectives for gene expression markers selection. Maydica 56:61-69.

Benešová, M., Holá, D., Fischer, L., Jedelský, P.L., Hnilička, F., Wilhelmová, N., Rothová, O., Kočová, M., Procházková, D., Honnerová, J., Fridrichová, L., Hniličková, H. 2012. The physiology and proteomics of drought tolerance in maize: Early stomatal closure as a cause of lower tolerance to short-term dehydration? PLoS ONE 7(6):e38017.

Campbell, S.A., Close, T.J. 1997. Dehydrins: genes, proteins, and associations with phenotypic traits. New Phytologist 137:61-74.

Capelle, V., Remoué, C., Moreau, L., Reyss, A., Mahé, A., Massonneau, A., Falque, M., Charcosset, A., Thévenot, C., Rogowsky, P., Coursol, S., Prioul, J.L. 2010. QTLs and candidate genes for desiccation and abscisic acid content in maize kernels. BMC Plant Biology 10. doi:10.1186/1471-2229-10-2.

Chazen, O., Neumann, P.M. 1994. Hydraulic signals from the roots and rapid cell-wall hardening in growing maize (Zea mays L.) leaves are primary responses to polyethylene glycol-induced water deficits. Plant Physiol. 104:1385-1392. 
Close, T.J. 1997. Dehydrins: A commonalty in the response of plants to dehydration and low temperature. Physiol. Plant. 100:291-296.

Doorenbos, J., Kassam, A.H. 1979. Yield response to water. FAO Irrigation and drainage paper No. 33. Food and Agriculture Organization of the United Nations. Rome, Italy.

Ganeshan, S., Denesik, T., Fowler, D.B., Chibbar, R.N. 2009. Quantitative expression analysis of selected low temperature-induced genes in autumn-seeded wheat (Triticum aestivum L.) reflects changes in soil temperature. Environ. Exp. Bot. 66:46-53.

Gavloski, J.E., Whitfield, G.H., Ellis, C.R. 1992. Effect of restricted watering on sap flow and growth in corn (Zea mays L.). Can. J. Plant Sci. 72:361-368.

Gholipoor, M., Sinclair, T.R., Raza, M.A.S., Löffler, C., Cooper, M., Messina, C.D. 2013. Maize hybrid variability for transpiration decrease with progressive soil drying. J. of Agron. and Crop Sci. 199:23-29.

Gómez-Anduro, G., Ceniceros-Ojeda, E.A., Casados-Vázquez, L.E., Bencivenni, C., Sierra-Beltrán, A., Murillo-Amador, B., Tiessen, A. 2011. Genome-wide analysis of the beta-glucosidase gene family in maize (Zea mays L. var B73). Plant Mol. Biol. 77:159-183.

Grzesiak, M.T., Marcińska, I., Janowiak, F., Rzepka, A., Hura, T. 2012. The relationship between seedling growth and grain yield under drought conditions in maize and triticale genotypes. Acta Physiol. Plant. 34:1757-1764.

Grzesiak, M.T., Waligórski, P., Janowiak, F., Marcińska, I., Hura, K., Szczyrek, P., Głąb, T. 2013. The relations between drought susceptibility index based on grain yield $\left(\mathrm{DSI}_{\mathrm{GY}}\right)$ and key physiological seedling traits in maize and triticale genotypes. Acta Physiol. Plant. 35:549-565.

Guo, P., Baum, M., Grando, S., Ceccarelli, S., Bai, G., Li, R., Korff, M., Varshney, R.K., Graner, A., Valkoun, J. 2009. Differentially expressed genes between drought-tolerant and drought-sensitive barley genotypes in response to drought stress during the reproductive stage. J. Exp. Bot. 60:3531-3544.

Jacovides, C.P., Tymvios, F.S., Asimakopoulos, D.N., Theofilou, K.M., Pashiardes, S. 2003. Global photosynthetically active radiation and its relationship with global solar radiation in the Eastern Mediterranean basin. Theor. Appl. Climatology 74:227-233.

Jamieson, P.D., Francis, G.S., Wilson, D.R., Martin, R.J. 1995. Effects of water deficits on evapotranspiration from barley. Agric. For. Meteorol. 76:41-58.

Jia, J., Fu, J., Zheng, J., Zhou, X., Huai, J., Wang, J., Wang, M., Zhang, Y., Chen, X., Zhang, J., Zhao, J., Su, Z., Lv, Y., Wang, G. 2006. Annotation and expression profile analysis of 2073 full-length cDNAs from stress-induced maize (Zea mays L.) seedlings. Plant J. 48:710-727.

Klimešová, J., Středová, H., Středa, T. 2013. Maize transpiration in response to meteorological conditions. Contributions to Geophysics and Geodesy 43:225-236.

Koag, M.C., Fenton, R.D., Wilkens, S., Close, T.J. 2003. The binding of maize DHN1 to lipid vesicles. Gain of structure and lipid specificity. Plant Physiol. 131:309-316.

Kučera, J., Čermák, J., Penka, M. 1977. Improved thermal method of continual recording the transpiration flow rate dynamics. Biologia Plantarum 19:413-420.

Leitner, D., Meunier, F., Bodner, G., Javaux, M., Schnepf, A. 2014. Impact of contrasted maize root traits at flowering on water stress tolerance - A simulation study. Field Crops Res. 165:125-137.

Li, X-H., Liu, X-D., Li, M-S., Zhang, S.-H. 2003. Identification of quantitive trait loci for anthesis-silking interval and yield components under drought stress in maize. Acta Botanica Sinica 45:852-857.

Matejka, F., Hurtalová, T., Rožnovský, J., Chalupníková, B. 2005. Effect of soil moisture on evapotranspiration of a maize stand during one growing season. Contributions to Geophysics and Geodesy 35:219-228.

Meier, U. 1997. BBCH-Monograph. Growth stages of plants - Entwicklungsstadien von Pflanzen - Estadios de las plantas - Développement des Plantes. Blackwell Wissenschaftsverlag. Berlin, Germany. 622 p.

Novák, V., Hurtalová, T., Matejka, F. 2005. Predicting the effects of soil water content and soil water potential on transpiration of maize. Agric. Water Manage. 76:211-223.

Pfaffl, M.W. 2001. A new mathematical model for relative quantification in real-time RT-PCR. Nucleic Acids Res. 29:e45.

Pfaffl, M.W., Tichopad, A., Prgomet, C., Neuvians, T.P. 2004. Determination of stable housekeeping genes, differentially regulated target genes and sample integrity: BestKeeper - Excel-based tool using pair-wise correlations. Biotechnol. Letters 26:509-515. 
Ribaut, J.M., Hoisington, D.A., Deutsch, J.A., Jiang, C., Gonzalez de Leon, D. 1996. Identification of quantitative trait loci under drought conditions in tropical maize. I. Flowering parameters and the anthesis-silking interval. Theor. Appl. Genet. 92:906-914.

Tommasini, L., Svensson, J.T., Rodriguez, E.M., Wahid, A., Malatrasi, M., Kato, K., Wanamaker, S., Resnik, J., Close, T.J. 2008. Dehydrin gene expression provides an indicator of low temperature and drought stress: transcriptome-based analysis of barley (Hordeum vulgare L.). Functional and Integrative Genomics 8:387405.

Valluru, R., Davies, W.J., Reynolds, M.P., Dodd, I.C. 2016. Foliar abscisic acid to ethylene accumulation and response regulate shoot growth sensitivity to mild drought in wheat. Frontiers in Plant Science 7:461.

Vilardell, J., Goday, A., Freire, M.A., Torrent, M., Martínez, M.C., Torné, J.M., Pagès, M. 1991. Gene sequence, developmental expression, and protein phosphorylation of RAB-17 in maize. Plant Mol. Biol. 14:423-432.

Vítámvás, P., Urban, M.O., Škodáček, Z., Kosová, K., Pitelková, I., Vítámvás, J., Renaut, J., Prášil, I.T. 2015. Quantitative analysis of proteome extracted from barley crowns grown under different drought conditions. Frontiers in Plant Science 6:479.

Wood, A.J., Goldsbrough, P.B. 1997. Characterization and expression of dehydrins in water-stressed Sorghum bicolor. Physiol. Plant. 99:144-152.

Wu, Y., Huang, M., Warrington, D.N. 2011a. Responses of different physiological indices for maize (Zea mays) to soil water availability. Pedosphere 21:639-649.

Wu, Y., Huang, M., Warrington, D.N. 2011b. Growth and transpiration of maize and winter wheat in response to water deficits in pots and plots. Environ. Exp. Bot. 71:65-71.

Zheng, J., Zhao, J., Tao, Y., Wang, J., Liu, Y., Fu, J., Jin, Y., Gao, P., Zhang, J., Bai, Y., Wang, G. 2004. Isolation and analysis of water stress induced genes in maize seedlings by subtractive PCR and cDNA macroarray. Plant Mol. Biol. 55:807-823.

Zinselmeier, Ch., Sun, Y., Helentjaris, T., Beatty, M., Yang, S., Smith, H., Habben, J. 2002. The use of gene expression profiling to dissect the stress sensitivity of reproductive development in maize. Field Crops Res. 75:111-121.

\section{Electronic Supplementary Material (ESM)}

Electronic Supplementary Material (ESM) associated with this article can be found at the website of CRC at http://www.akademiai.com/content/120427/

Electronic Supplementary Table S1. Correlations between the average diurnal sap flow values of maize plants grown under different soil moisture conditions (A, B, C, D) and meteorological variables (air temperature and global solar radiation) for three periods (Period I $n=10$; Period II $n=18$; Period III $n=20$ ) 